\title{
Correspondence
}

\section{Chocolate habits of Nobel prizewinners}

There is a reported correlation between chocolate consumption by different nations and the number of Nobel laureates in their populations (F. H. Messerli New Engl. J. Med. 1562-1564; 2012). So what are the chocolate habits of Nobel prizewinners?

We surveyed 23 male winners of the Nobel prize in physics, chemistry, physiology or medicine, and economics. Ten (43\%) reported eating chocolate more than twice a week, compared with only $25 \%$ of 237 well-educated age- and sex-matched controls $(P=0.05$; see B. A. Golomb et al. Arch. Intern. Med. 172, 519-521; 2012). Three proffered that their chocolate consumption had indeed contributed to their Nobel prize, but most disavowed any link. Two attested that they had won the prize in spite of their chocolate habits (see also 'Nobel laureates on chocolate' and go.nature.com/copuha).

Some laureates might understate their chocolate consumption to amplify the impression that native prowess led to their prize, producing bias to the null. However,

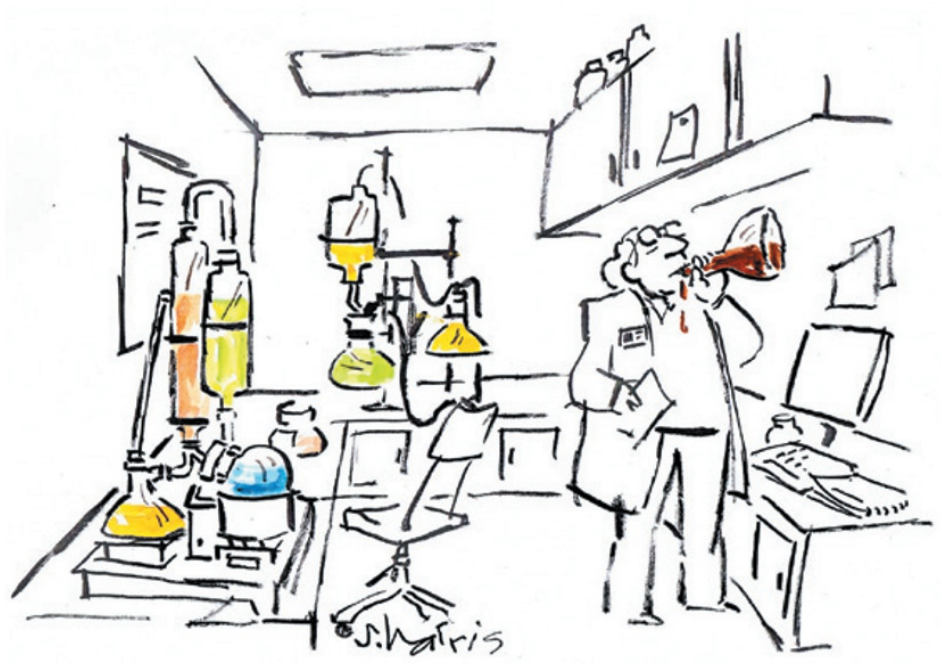

given favourable chocolatemortality associations, chocolate aficionados might have survived to get their just desserts.

Another caveat is that the laureates' responses, like chocolate consumption itself, could be tongue in cheek.

Beatrice A. Golomb* University of California, San Diego, California, USA. bgolomb@ucsd.edu ${ }^{*}$ On behalf of 14 co-authors (see go.nature.com/b5rz8h for a full list).

\section{COCOA CONNECTION}

\section{Nobel laureates on chocolate}

"Laureates are handed chocolate replicas of the medal in gold foil at the Nobel ceremony. This must mean that the Nobel Foundation thinks chocolate is important."

"My wife is a chocoholic but so far has not received the phone call."

"Chocolate made me who I am today."

"The correlation could stimulate even greater efforts to compete with the Swiss, French and Belgians."

"Your research is poised precisely in the vast space between balanced objectivity and total confusion."

"I eat a lot of wine gums and biltong in case you are considering snacking in general."

"I am upping my chocolate consumption to recapture my youthful IQ."

\section{Future food: politics plague seed banks}

As a former head of the gene bank at the International Center for Tropical Agriculture (CIAT), I feel that Susan McCouch and others underestimate the political problems facing seed banks particularly with respect to access to new samples (Nature 499, 23-24; 2013).

I disagree that the Convention on Biological Diversity "has created significant barriers to the sharing of genetic material". Most of the banked seed samples that are shared internationally or used by plant breeders are beyond the control of the convention including those from the institutes of the Consultative Group on International Agricultural Research (CGIAR) and the US Department of Agriculture.

Neither does the International Treaty on Plant Genetic Resources for Food and Agriculture "now govern access to crop diversity". The United States, Russia, China, South Africa and 61 other countries have not ratified the treaty.

CGIAR holdings were included in the treaty on the understanding that they would remain freely available subject to a small tax (payable to the Food and Agriculture Organization of the
United Nations for the treaty's benefit-sharing fund) on patented varieties derived from supplied samples.

The treaty also excludes some important crops, such as soya beans, groundnut, tomatoes, wild cassava, some wild wheat and maize (corn) varieties, sugar cane, oil palm and most fruits and nuts.

In my view, the treaty needs to include many more countries and be much more effective at ensuring access to seed samples, if it is to be a success.

Dave Wood Fyvie,

Aberdeenshire, UK. agrobiodiversity@btinternet.com

\section{Future food: use local knowledge}

Efforts to mine seed banks and secure future food supplies would benefit from participation by farmers, who could help to develop crop varieties suitable for their own land-management systems (Susan McCouch et al. Nature 499, 23-24; 2013).

Farmers usually optimize land usage to supply year-round nutrition, to cater for cultural preferences and ecosystem services, to provide income, reduce labour and avoid economic risk.

Integrating these practices could enhance the success of crop-breeding efforts. In this age of information sharing, even remote farmers could now become directly involved in and take advantage of a globally accessible infrastructure of biodiversity informatics that incorporates local knowledge.

Such a biocultural informatics programme might add expense, but it would ultimately improve the costeffectiveness of global food security and health.

Selena Ahmed Tufts University, Medford, Massachusetts, USA. selena.ahmed@tufts.edu Anna Herforth Cornell University, Ithaca, New York, USA. 